\title{
UNIVERSITY OF PENNSYLVANIA RADIOCARBON DATES XVII
}

\author{
BARBARA LAWN
}

Department of Physics and University Museum,

University of Pennsylvania, Philadelphia, Pennsylvania 19174

\section{INTRODUCTION}

This date list includes most of the archaeologic and geologic samples dated in this laboratory since publication of our last date list ( R, v 13, p 367-381), as well as some samples dated previously, which lacked adequate sample information. Known-age samples are reported in Univ of Pennsylvania Radiocarbon Dates XVI, this issue. The вP ages are based on AD 1950, and have been calculated with the half-life value of $5568 \mathrm{yr}$. All samples were counted at least twice for periods of not less than $1000 \mathrm{~min}$ each. Errors quoted for each sample are derived from the measurement of the sample, the background, and several counts of our mid-19th century standard Oak sample, but do not include the half-life error. All samples were pretreated with $3 \mathrm{~N}$ HCL, and some, where noted, were given additional pretreatment with $2 \% \mathrm{NaOH}$ for the removal of possible humic acid contaminants.

Our mid-19th century calibration samples have an average age of $126 \mathrm{yr}$. When corrected for this age, they have ${ }^{14} \mathrm{G}$ contents equal to $95 \%$ of the NBS oxalic acid standard. The average ${ }^{13} \mathrm{C}$ relationship between the Oak standards and the NBS limestone standard \#20 is $-25.7 \pm 1.3 \%$ as measured on the Univ of Pennsylvania mass spectrograph. Where $\delta^{13} \mathrm{C}_{\mathrm{w}}$ is reported, the ${ }^{13} \mathrm{C}$ relationship has been measured with respect to the Oak standard and the results are accordingly corrected for isotopic fractionation.

The MASCA corrected ranges, appearing in the sample comments, are maximum ranges and have been arrived at by applying appropriate correction factors to dates calculated with the 5730 half-life. For further explanation, see Univ of Pennsylvania Dates XVI, this issue, and Ralph et al, 1973. samples.

I wish to thank Ray Costa for his careful work in processing these

\section{SAMPLE DESCRIPTIONS}

I. ARChaEOLOGIC SAMPLES

\section{Italy}

A. Mediterranean

\section{Cosa series}

Samples from inner Harbor area at Cosa, Ansedonia, Italy $\left(42^{\circ} 24^{\prime}\right.$ N, $11^{\circ} 17^{\prime} \mathrm{E}$ ). Coll Aug 1972; subm by A M McCann, Univ California at Berkeley. For additional dates for this site, see P-1594 and -1722 (R, 1973, v 15, p 368).

General Comment: wood id by R C Koeppen, Forest Prods Lab, US Dept Agric, Madison, Wisconsin. 


\section{P-1931. PC-72-WS-1}

Wood, Sample PC-72-WS-1, red pine group, (Pinus) from fragment of ancient Roman beam from device in Roman Fountain House, over underground springs. Water-lifting device believed to date from later stages of Fountain House, with latest pottery material from 2nd century AD. Comment: MASCA corrected range: 740 to 840 BC.

\section{P-1932. PC-72-WS-2}

$1990 \pm 50$

Plank, PC-72-WS-2, European Spruce (Picea abies) from cofferdam surrounding Roman rubble wall in $\operatorname{Tr} \mathrm{YZ} \# 3$ ancient layer silted over 1st century BC. Cofferdam thought to be a dock from that date, or a fishing tank of a later date. Comment: MASCA corrected range: AD 60 to $110 \mathrm{BC}$.

\section{P-1933. PC-72-WS-3}

$3270 \pm 70$

Wood, PC-72-WS-3, white oak group, (Quercus) from cofferdam, Tr IA, to $S$ of Pedestal \#3. Comment: MASCA corrected range: 1520 to 1710 BC.

\section{P-1934. PC-72-WS-4}

$1980 \pm 60$

Wood, PC-72-WS-4, pine, (Pinus) from cofferdam surrounding rubble wall, from Tr IB, W face of wall, believed to be fish tank of 2nd century AD. Comment: MASCA corrected range: AD 70 to $120 \mathrm{BC}$.

\section{P.1935. PC-72-WS-5}

$1860 \pm 60$

Wood, PC-72-WS-5, red oak group, (Quercus) from cofferdam surrounding ancient Roman wall, believed to be a dock. Sample from $\mathrm{Tr}$ U1, to E of Wall U. Comment: MASCA corrected range: AD 130 to 60 .

\section{Greece}

\section{Franchthi Cave series}

Franchthi Cave $\left(37^{\circ} 26^{\prime} \mathrm{N}, 23^{\circ} 8^{\prime} \mathrm{E}\right)$ is near W tip of high, rugged headland, directly across bay from village of Koilada near Porto Cheli in S Argolid, Peloponnese, Greece. Site is especially important for its apparently continuous stratigraphic sequence from late Paleolithic through Mesolithic and the critical transition to Neolithic. There are no stratified prehistoric remains beyond Late Neolithic. Samples coll 1971; subm by $\mathrm{T} \mathrm{W}$ Jacobsen, Indiana Univ, Bloomington, and $\mathrm{M} \mathrm{H}$ Jameson, Univ Mus, Univ Pennsylvania, Philadelphia (Jacobsen, 1968; 1969a, b, and c). For additional dates from this site, see R, 1971, v 13, p 364-367.

General Comment: with exception of P-1920 (cf) all dates are beyond range of MASCA correction factors now available (Oct, 1973). See Pennsylvania XVI, this issue, and Ralph et al, 1973. 


\section{P-1920. F/A Balk, Unit 83S}

$6170 \pm 60$

4220 BC

Charcoal mixed with dark reddish gray earth from F/A Balk, Unit 83S, underlying P-1660: $5260 \pm 60$ (R, 1971, v 13, p 364). Date expected to be late Neolithic. Comment: MASCA corrected range: 5050 to $5240 \mathrm{BC}$.

\section{P-1921. F/A Balk, Unit 102S}

$\mathbf{8 4 1 0} \pm 90$

Charcoal mixed with dark reddish brown earth from $\mathrm{F} / \mathrm{A}$ Balk, Unit 102S, underlying P-1920 (cf P-1920). Date expected to be Late Neolithic.

\section{P.1922. F/A Balk, Unit 129N}

$6790 \pm 90$

Charcoal mixed with dark brown earth from F/A Balk, Unit 129N. Date expected to be Middle Neolithic.

\section{P-1922-A. F/A Balk, Unit 129N}

$6730 \pm 70$

$4780 \mathrm{BC}$

Same as P-1922. Comment: $\mathrm{NaOH}$ pretreatment. Sample was run with and without $\mathrm{NaOH}$ pretreatment as a test for humic contamination in site. Date expected to be Middle Neolithic.

\section{P-1824. F/A Balk, Unit 137N}

$6670 \pm 70$

Charcoal and dark brown earth from F/A Balk, Unit 137N, underlying P-1922 (cf). Date expected to be Middle Neolithic.

\section{P-1923. H-1, Unit A181}

$11,240 \pm 140$

$9290 \mathrm{BC}$

Charcoal and dark red earth with many crushed snail shells, overlying P-1520: 11,090 $\pm 260(\mathrm{R}, 1971, \mathrm{v} 13, \mathrm{p}$ 367). Date expected to be upper Paleolithic.

\section{P-1827. H-1, Unit A199}

$12,540 \pm 180$

Charcoal and reddish brown earth; same level as P-1520; 11,090 \pm 260 (R, 1971, v 13, p 367). Date expected to be Upper Paleolithic.

\section{Iran}

\section{B. Near East}

\section{Hajji Firuz Tepe series}

Hajji Firuz Tepe $\left(37^{\circ} \mathrm{N}, 45^{\circ} 29^{\prime} \mathrm{E}\right)$, is a small mound SE of Hasanlu Tepe on $S$ shore of Lake Urmia, in Solduz valley of Azerbaijan Prov, Iran. Excavated by Univ Mus, 1958, 1959, 1961, and 1968. Samples coll 1968; subm by R H Dyson, Jr, Univ Mus, Univ Pennsylvania, Philadelphia (1965, 1969; Lawn, 1970; Ralph, 1959; Stuckenrath, 1963; Stuckenrath et al, 1966). 


\section{P-1839. HF 68-S-68}

$$
\begin{array}{r}
\mathbf{8 7 0} \pm \mathbf{5 0} \\
\mathbf{A D} \mathbf{1 0 8 0} \\
{ }^{13} C_{w}=+1.90 \%
\end{array}
$$

Reed matting, burnt in situ, from bottom or rectangular pit in F 11 (2). Sample dates Islamic occupation of mound and assoc ceramic assemblage. Comment: $\mathrm{NaOH}$ pretreatment. ${ }^{13} \mathrm{C} /{ }^{12} \mathrm{C}$ was measured as some reed samples are known to be fractionated; this one, however, had not. MASCA range: AD 1100 to 1040.

\section{P-1841. HF 68-S-70}

$5460 \pm 80$

Charcoal, from Operation F 10 (2) 1 dates Chalcolithic (Pisdeli or Hasanlu VIII period) occupation of site. For other dates for this period see P-866: $5450 \pm 70(\mathrm{R}, 1966, \mathrm{v}$ 8, p 350); P-157: $5450 \pm 160$ (R, 1959, v 1, p 50); P-504: $5520 \pm 80$ and P-505: $5640 \pm 80$ (R, 1963, v 5, p 89). Comment: MASCA corrected range: 4270 to $4400 \mathrm{BC}$.

\section{P-1842. HF 68-S-73}

$5370 \pm 80$

Charcoal from Operation F 10 (3a) 4 dates Chalcolithic occupation (Pisdeli or Hasanlu VIII period) of site. For other dates for this period, see P-1841 (cf). Comment: MASCA corrected range: 4100 to 4380 BC.

\section{P.1843. HF 68-S-76}

$6870 \pm 100$

Charcoal from Operation H 12 (6) 2 on lower floor of "Stolper House", assoc with trash heap and Burial 3 (Dyson, 1969). For date from stratigraphically equivalent samples, see P-502: $6900 \pm 80$, and P-455: $7270 \pm 90(\mathrm{R}, 1963, \mathrm{v} 5, \mathrm{p} 90)$. Comment: this sample is beyond range of MASCA correction factors now available (Oct, 1973). See Pennsylvania XVI, this issue, and Ralph et al, 1973.

\section{Lebanon}

\section{Sarafand series}

Sarafand (ancient Sarepta), Lebanon $\left(33^{\circ} 27^{\prime} \mathrm{N}, 35^{\circ} 17^{\prime} \mathrm{E}\right)$ is adjacent to harbor of village of Sarafand, ca $12.87 \mathrm{~km} \mathrm{~S}$ of Sidon on road to Tyre. Site represents most extensive and best stratigraphic remains of Phoenician civilization yet excavated. Samples coll 1972, subm 1972 by J B Pritchard, Univ Mus, Univ Pennsylvania, Philadelphia.

\section{P-1944. II-D-6}

$3160 \pm 60$

Charcoal from firing chamber of Kiln S. Comment: $\mathrm{NaOH}$ pretreatment. MASCA corrected range: 1460 to 1600 вс.

\section{P-1945. Rm 65, Level 4A kiln}

$$
2360 \pm 60
$$

Charcoal. Comment: $\mathrm{NaOH}$ pretreatment. MASCA corrected range: 430 to 660 вС. 
P.1946. II-A-9, Level 7

$3000 \pm 50$

Charcoal. Comments: $\mathrm{NaOH}$ pretreatment. MASCA corrected range: 1220 to 1400 BC. (JBP): MASCA corrected range agrees well with analysis of pottery assoc with this level. Pottery assoc with other levels are not yet analyzed.

\section{P-1947. II C-4, Level 7.9}

$2880 \pm 60$

Charcoal. Comment: MASCA corrected range: 1020 to 1260 BC.

P-1948. II-B-4, Level 8

$2920 \pm 50$

Charcoal. Comment: MASCA corrected range: 1110 to 1300 BC.

\section{P-1950. II-C-5, Level 8-3}

$2950 \pm 50$

1000 BC

Charcoal from Level 8-3*sealed. Comment: $\mathrm{NaOH}$ pretreatment. MASCA corrected range: 1160 to $1360 \mathrm{BC}$.

\section{P-1951. II-C-5, Level 10-1}

$2990 \pm 50$

Charcoal from Level 10-1*sealed. Comment: $\mathrm{NaOH}$ pretreatment. MASCA corrected range: 1220 to 1390 Bс.

\section{Turkey}

\section{Korucu Tepe series}

Korucu Tepe is a medium-sized mound in the Altimova plain $\mathrm{E}$ of Elazig, Turkey $\left(38^{\circ} 42^{\prime} \mathrm{N}, 39^{\circ} 30^{\prime} \mathrm{E}\right)$, at alt ca $824 \mathrm{~m}$. Samples coll 1970; subm by Maurits van Loon, Inst Prae-en Protohist, Univ Amsterdam, Amsterdam, Netherlands (van Loon and Buccellati, 1969, 1970; Mellink, 1969, 1970). For more dates from this site, see P-1611-1618 and P-1626-1629 (R, 1971, v 13, p 368-369).

\section{P-1927. KRC 70-S439}

$3950 \pm 70$

Charcoal from Operation O 16, Area 4, Level 10. From area next to heavy mud brick wall of Early Bronze III public building on top of Korucu Tepe, assoc with fluted black burnished pottery and clay figurines of ca 2300 to 2000 BC. Early Bronze III building was abandoned, but never burned and charcoal was found next to burned Early Bronze II level, into which foundations were dug. Thus, sample may predate ca 2300 вс. Comment: $\mathrm{NaOH}$ pretreatment. MASCA corrected range: 2420 to 2670 BC.

\section{P-1926. KRC 70-S670}

$4340 \pm 70$

Charcoal, from Operation P 17, Area 13, Level 5, from floor of burned room containing relief-decorated black burnished pottery and a clay "andiron", similar to those found in Amuq Phase H-1 (Braidwood 
\& Braidwood, 1960, p 358-368; 398-403; 518-519). Dating this locus will establish whether it is contemporary with loci elsewhere on Korucu Tepe which yielded undecorated black burnished pottery with the following dates: P-1617-A, $4110 \pm 70$; P-1617-b, $4070 \pm 60$; P-1618, $4220 \pm$ 60; P-1628, $3990 \pm 60$; and P-1629, $3960 \pm 70$ (R, 1971, v 13, p 368-369). Comment: $\mathrm{NaOH}$ pretreatment. MASCA corrected range: 2970 to $3180 \mathrm{BC}$.

\section{P-1928. KRC 70-S948}

$$
5150 \pm 80
$$

Charcoal from Operation K 12, Area 14, Level 22, on Floor W. Coll from floor of burned room containing chaff-faced pottery comparable to Amuq F ware (Braidwood \& Braidwood, 1960, p 232-238; 513514) and some pie-shaped clay structures which probably served as pot stands. K 12, Level 22 is above K 12, Level 27, dated $5370 \pm 40$, GrN5286 , and $5330 \pm 40, \mathrm{GrN}-5287$ (pers commun). Comment: $\mathrm{NaOH}$ pretreatment. MASCA corrected range: 3820 to 4090 вс.

\section{P-1929. KRC 70-S757}

$6310 \pm 70$

Charcoal from Operation K 13, Area 5, Level 27. Coll from burned horizontal timber incorporated into plastered mud brick house wall in earliest building level found at Korucu Tepe. Assoc pottery is black or brown burnished, with a few Halaf and Ubaid-like sherds, pointing to a date ca 4500 to 4000 BC (Braidwood \& Braidwood, 1960, p 157-168; 509511). Comment: $\mathrm{NaOH}$ pretreatment, MASCA corrected range: 5180 to 5300 BC.

\section{Syria}

\section{Selenkahiye series, Syria}

Selenkahiye is a fortified mound $87 \mathrm{~km} \mathrm{E}$ of Aleppo, Syria $\left(36^{\circ} 6^{\prime} \mathrm{N}\right.$, $38^{\circ} 3^{\prime} \mathrm{E}$ ) on W bank of Euphrates R. Samples coll 1967 during excavations by Oriental Inst Univ Chicago; subm 1970 by Maurits van Loon (1968, 1969; van Loon and Dornemann, 1969).

Phase 1: 1st occupation on natural levee along Euphrates R, apparently Early Dynastic period, ca 2600 to 2300 BC.

\section{P.1788. SLK S67-192}

$3900 \pm 60$ $1950 \mathrm{BC}$

Charcoal from Operation W41, Area 6, Level EL, ca $20 \mathrm{~cm}$ above virgin soil. Comment: $\mathrm{NaOH}$ pretreatment. MASCA corrected range: 2210 to 2580 вс.

\section{P.1789. SLK S67-194}

$3860 \pm 70$

Charcoal from Operation W41, Area 6, to virgin soil in level E-H. Comment: $\mathrm{NaOH}$ pretreatment. MASCA corrected range: 2190 to $2560 \mathrm{BC}$. Phase 2: construction of mud brick city wall with stairs at regular intervals_possibly Early Akkad period, ca 2300 to 2225 BC. 
P.1790. SLK S67-101

$12,810 \pm 230$

Charcoal from Operation W41, Area 5, bottom of Level 5. Comment: not tested for bitumen because all of sample had already been processed for dating. Cf P-1791, below.

\section{P-1791. SLK S67-141}

$+2890$

Charcoal, from Operation W41, Area 5, bottom of Level E2. Comment: $\mathrm{NaOH}$ pretreatment. After dating, an unburnt portion of sample was tested and found to be contaminated with bitumen. Use of bitumen is recorded in excavation rept (van Loon and Dornemann, 1969, p 66).

Phase 4: renovation of public building-possibly Ur III period, ca 2150 to $2000 \mathrm{BC}$. This phase ended in wholesale slaughter and fire.

\section{P-1792. SLK S67-124}

$3970 \pm 70$

Charcoal from Operation W43, Area 4, floor of Level 3. Comment: $\mathrm{NaOH}$ pretreatment. MASCA corrected range: 2480 to $2780 \mathrm{BC}$.

\section{P-1793. SLK S67-193}

$3790 \pm 60$ $1840 \mathrm{BC}$

Charcoal from charred roof of burnt building in Operation $\mathrm{X} 43$, Area 4, Level 2. Comment: $\mathrm{NaOH}$ pretreatment. MASCA corrected range: 2170 to $2460 \mathrm{BC}$.

\section{P-1794. SLK S67.437}

$\mathbf{3 6 2 0} \pm \mathbf{5 0}$

Charcoal from burnt roof beams found on floor of doorway in Operation X43, Area 4, Level 5. Comment: $\mathrm{NaOH}$ pretreatment. MASCA corrected range: 2070 to $2160 \mathrm{BC}$.

Phase 5: re-occupation of ruined public building by private householdspossibly ca 2000 to 1950 BC.

\section{P-1795. SLK S67.315}

$3930 \pm 60$ $1980 \mathrm{BC}$

Charcoal from Operation W42, Area 3, floor next to oven of Level 1. Comment: $\mathrm{NaOH}$ pretreatment. MASCA corrected range: 2340 to $2610 \mathrm{BC}$.

\section{P.1796. SLK S67-391}

$3880 \pm 60$

Charcoal from Operation W42, Area 3, level next to oven. Comment: $\mathrm{NaOH}$ pretreatment. MASCA corrected range: 2190 to 2560 BC.

Phase unknown. 


\section{P.1797. SLK S67-191}

Charcoal from Operation Q26, Area 2, Level 14, from locus next to E balk. Comment: $\mathrm{NaOH}$ pretreatment. MASCA corrected range: 2150 to 2330 вс.

P.1798. SLK S67-83

$4080 \pm 60$

Charred grain and soil from Operation Q26, Area 2, Level 7. Comment: $\mathrm{NaOH}$ pretreatment. MASCA corrected range: 2610 to $2910 \mathrm{BC}$.

\section{Afghanistan}

\section{Southwest Asia}

\section{Ai-Khanoum series}

Ai-Khanoum in Bactria, $\mathrm{N}$ Afghanistan $\left(37^{\circ} 10^{\prime} \mathrm{N}, 69^{\circ} 24^{\prime} \mathrm{E}\right)$ is 1 st Hellenistic site discovered there. Samples coll 1969; subm by Paul Bernard, Dir, Delegation Archaeol Francaise en Afghanistan, Kabul, Afghanistan. All charcoal (Platanus orientalis) id by R C Koeppen.

\section{P.1872. Hypostyle Hall, late floor}

Charcoal from burnt roof beam. Expected date 1st century BC. Comment: $\mathrm{NaOH}$ pretreatment. MASCA corrected range: 910 to $1100 \mathrm{BC}$.

\section{P.1873. Hypostyle Hall, late floor}

Charcoal from burnt roof beam. Expected date 1st century BC. Comment: $\mathrm{NaOH}$ pretreatment. MASCA corrected range: 200 to 410 вс.

\section{P-1874-A. Hypostyle Hall, late floor}

Charcoal from burnt roof beam. Expected date 1st century BC. Comment: $\mathrm{NaOH}$ pretreatment. MASCA corrected range: 120 to $380 \mathrm{BC}$.

P-1875. Temple á redans, late floor

$3690 \pm 70$

Charcoal. Expected date 1st century BC. Comment: $\mathrm{NaOH}$ pretreatment MASCA corrected range: 2110 to $2180 \mathrm{BC}$.

P-1876. Temple á redans, late floor

$2170 \pm 50$

Charcoal. Expected date 1st century BC. Comment: $\mathrm{NaOH}$ pretreatment. MASCA corrected range: 170 to $400 \mathrm{BC}$.

P-1877. Temple á redans, late floor $2650 \pm 50$ $700 \mathrm{BC}$

Charcoal. Expected date 1st century BC. Comment: $\mathrm{NaOH}$ pretreatment. MASCA corrected range: 810 to $910 \mathrm{BC}$. 


\section{P-1878. Hypostyle Hall}

$$
\begin{aligned}
& \mathbf{2 6 5 0} \pm \mathbf{5 0} \\
& \mathbf{7 0 0} \mathbf{~ B C} \\
\delta^{13} C_{w}= & +19.53 \%
\end{aligned}
$$

Charcoal and burnt reed under earliest foundation of $\mathrm{W}$ wall. Expected date 3rd century BC. Comment: MASCA corrected range: 800 to
900 BC.

\section{P-1879. Hypostyle Hall}

$$
\begin{array}{r}
\mathbf{2 3 3 0} \pm \mathbf{5 0} \\
\mathbf{3 8 0} \mathbf{~ B C} \\
\delta^{13} C_{w}=+9.67 \% \text { o }
\end{array}
$$

Charcoal and burnt reed under earliest foundation of $\mathrm{W}$ wall. Expected date ca 3rd century BC. Comment: MASCA corrected range: 420 to 640 BC.

\section{P.1880. Hypostyle Hall}

$$
\begin{array}{r}
\mathbf{2 5 4 0} \pm \mathbf{5 0} \\
\mathbf{5 9 0} \mathrm{BC} \\
\delta^{13} C_{w}=+24.41 \% \circ
\end{array}
$$

Charcoal and burnt reed under earliest foundation of $\mathrm{W}$ wall. Expected date ca 3rd century BC. Comment: MASCA corrected range: 740 to $810 \mathrm{BC}$.

\section{1. $U S A$}

\section{North America}

\section{Dixthada series}

\section{Alaska}

Dixthada is a multicomponent site in central Alaska, USA, $\left(63^{\circ} 28^{\prime}\right.$ $\mathrm{N}, 143^{\circ} 26^{\prime} \mathrm{W}$ ), with a core and blade technology underlying a late prehistoric Athapaskan occupation characterized by extensive bone and copper utilization. Samples coll 1971 by J P Cook and R A McKennan; subm 1971 by J P Cook, Univ Alaska, College, Alaska (Cook \& McKennan, 1970; Rainey, 1939; 1940).

\section{P.1833. S106/E/98/E1/2}

$$
\begin{array}{r}
390 \\
\text { AD } 1560
\end{array}
$$

Charcoal, Sample 5, Sq S106/E/98/E1/2, from lowest part of late Athapaskan midden; under spruce layer, multiple floors to non-organic dark soil. Comment: MASCA corrected range: AD 1520 to 1420.

P-1832. S106/E102

$770 \pm 40$

Charcoal, Sample 3, Sq S106/E102, from lowest part of late prehistoric Athapaskan midden; lowest floor above yellow silt. Comment: MASCA corrected range: AD 1240 to 1180.

\section{P.1834. S102/E100}

$$
2420 \pm 60
$$

$470 \mathrm{BC}$

Charcoal, Sample 1, Sq S102/E100, in yellow silt, 6 to $10 \mathrm{~cm}$ below late prehistoric midden deposit. Directly assoc with microblade (N73/ E1SO). Comment: MASCA corrected range: 440 to $740 \mathrm{BC}$. 


\section{Anangula series}

Anangula site $\left(53^{\circ} 00^{\prime} \mathrm{N}, 168^{\circ} 51^{\prime} \mathrm{W}\right)$, is on Anangula (Ananiulak) $\mathrm{I}$, in E Aleutians. This is a single component site, 17 to $20 \mathrm{~m}$ above present sea level, characterized by unifacial tools, including many lamellar-flake tools. Samples coll June and July 1970 and subm by J S Aigner, Univ Connecticut, Storrs, Connecticut. For additional dates from this site, see P-1102, -1103, -1105, -1107 and -1108 (R, 1967, v 9, p 336-337) (Black \& Laughlin, 1964; Laughlin, 1963; Laughlin \& Marsh, 1954).

General Comment: these samples are beyond range of correction factors now available. See Pennsylvania XVI, this issue and Ralph et al, 1973.

\section{P.1836. F-12-s, w-11}

$6990 \pm 90$

Charcoal from living zone outside house, on soil formed on volcanic ash, at depth ca 1.5 from modern surface. Estimated age: 7800 to $8500 \mathrm{BP}$. Comment: $\mathrm{NaOH}$ pretreatment.

\section{P-1837. F-24-III \& Vd and F-25-III \& Vd}

$7790 \pm 110$ $\mathbf{5 4 8 0 ~ B C}$

Charcoal, Samples F-24-III, F-24-Vd, F-25-III, and F-25-Vd from continuous carbonaceous zone, ca 1.5 to $1.7 \mathrm{~m}$ from modern surface; probably temporally equivalent remains from zone clearly within a small hearth area. Hearth and house floor are resting on volcanic ash. Estimated age: 8000 to 8400 BP. Comment: $\mathrm{NaOH}$ pretreatment.

\section{P-1835. F-6-e-V, F-11-w-V}

$7000 \pm 90$

Charcoal, Samples F-6-e-V and F-1 l-w-V, from zone believed to relate to initial occupation, at depth ca $1.68 \mathrm{~m}$ from modern surface, probably outside major house in $\mathrm{E}$ and beneath fill from latter. Occupation rests on volcanic ash layer. Comment: $\mathrm{NaOH}$ pretreatment.

\section{Savich Farm series}

\section{New Jersey}

Savich Farm site, consisting of a village midden and burial, is in Marlton, Evesham Township, Burlington Co, New Jersey $\left(39^{\circ} 53^{\prime} \mathrm{N}, 74^{\circ}\right.$ 53' W). Samples coll 1968, 1969; subm by Richard Regensburg, Univ Mus, Univ Pennsylvania, Philadelphia.

\section{P-1777. Feature 114}

$$
\begin{array}{r}
610 \\
\text { AD } 1340
\end{array}
$$

Charcoal from late woodland refuse pit in top soil and extending into subsoil and archaic component. Pit contained 215 potsherds of 1 type, 1 triangular point, 1 whetstone, and many hearth stones. Same type of pottery from Overpeck site was dated AD 1200. Comment: MASCA corrected range: AD 1370 to 1300. 


\section{P-1778. Feature 114}

Same as for P-1777, above, except that this sample was baked for $20 \mathrm{~min}$ at $300^{\circ} \mathrm{F}$ the same day it was excavated. It was thought that bacterial action could alter results. Comment: this limited test proved theory was false. MASCA corrected range: AD 1380 to 1260.

\section{P-1779. Feature 128}

$3640 \pm 60$

Charcoal from hearth pit, typical of many from terminal Archaic component. Pit contained 1 quartzite point, 4 aragonite bases, red ocher, and 85 hearth stones. Miller Field site, $\mathrm{N}$ New Jersey, has same point types below level dated at 1700 BC. Comment: $\mathrm{NaOH}$ pretreatment. MASCA corrected range: 2080 to $2160 \mathrm{BC}$.

\section{P.1780. Feature 135}

$3530 \pm 70$

Charcoal from terminal Archaic hearth pit (different from P-1779, above) sealed off from Woodland component floor by at least $10.2 \mathrm{~cm}$ of soil. Comment: MASCA corrected range: 1920 to 2110 BC.

\section{P-1781. Feature 157}

$3820 \pm 60$

Charcoal will help date village midden and cremation cult of terminal Archaic component. Estimated date: ca 2000 BC. Comment: MASCA corrected range: 2180 to $2480 \mathrm{BC}$.

\section{P-1782. Feature 215}

$4290 \pm 60$

2340 BC

Charcoal from Feature 215, deeper than most of other features, and contained 2 points of period 3500 to 4000 BC? Comment: $\mathrm{NaOH}$ pretreatment. MASCA corrected range: 2930 to 3150 вС.

\section{El Salvador}

\section{E. Central America}

\section{Chalchuapa series}

Area of sites is near Chalchuapa, El Salvador $\left(13^{\circ} 59^{\prime} \mathrm{N}, 89^{\circ} 4 \mathrm{l}^{\prime} \mathrm{E}\right)$. Samples are from the following excavations: Laguna Cuzcachapa (LC), stratified Preclassic ceremonial and occupational deposit; and El Trapiche mound group (TR), late Preclassic ceremonial center. Samples coll 1967 and 1969; subm by R J Sharer, (1969) Univ Mus, Univ Pennsylvania, Philadelphia.

\section{Laguna Cuzcachapa}

\section{P-1803. LC-2-8.5A}

Charcoal from Test Pit 2-8, Level 5. Date should be no later than late Preclassic. Comment: MASCA corrected range: AD 320 to 170. 
P-1807. LC-2-3.11(W)

$3610 \pm 60$

$1660 \mathrm{BC}$

Charcoal from Test Pit 2-3, Level 11 (lowest level). Date should be no later than terminal Early Preclassic. Comment: undersized sample, $85.63 \%$. MASCA corrected range: 2050 to 2150 вс.

\section{El Trapiche Mound}

\section{P-1547. TR-10-1-38A}

$1840 \pm 40$

Charcoal found within an intact ceramic cache vessel (Aguacate Orange: Atecozol variety) typical of Caynace Ceramic complex, са 300 BC to AD 200 or Late Preclassic. Stratigraphic position of cache indicates its contemporaneity with period of active use of structure E 3-1. Comment: undersized sample, $92.39 \%$. MASCA corrected range: AD 180 to 110 .

\section{P-1550. TR-10-2-30A}

$$
\begin{gathered}
2040 \pm 40 \\
90 \mathrm{BC}
\end{gathered}
$$

Charcoal found within vessel from Cache 10. Vessel type (Pinos black-brown: Apopa variety) as well as others from same cache, are all from Caynac Ceramic complex, (ca 300 BC to AD 200). Cache was assoc with particular construction phase of Structure E 3-1, (Stage 5), and sealed by subsequent construction phase. Comment: undersized sample, $96.08 \%$. MASCA corrected range: AD 10 to 160.

\section{P-1805. TR-10-7.3(A)}

$1970 \pm 60$

Charcoal from fill of Structure E 3-1. Date should be no later than Late Preclassic. Comment: MASCA corrected range: AD 70 to 110 BC.

\section{P-1806. TR-10-7.3(B)}

$$
2390 \pm 60
$$

Charcoal from fill of Structure E 3-1. Date should be no later than Late Preclassic. Comment: MASCA corrected range: 430 to 730 BC.

\section{P-1808. TR-10-15.B}

$24.50 \pm 60$

Charcoal from fill of Structure E 3-1. Date should be no later than Late Preclassic. Comment: MASCA corrected range: 480 to 780 вс.

\section{P-1551. TR-10-3-11A}

$2790 \pm 60$

840 BC

Charcoal found within apparently primary deposit of domestic debris at base of structure E 3-1. Deposit is dated as Terminal Early Preclassic, based on ceramic content, sherds of Tok Ceramic complex, ca 1000 to 900 BC. It overlay sterile soil (talpetate) and underlay Late Preclassic fill of Structure E 3-1. Comment: MASCA corrected range: 940 to 1100 BC. 


\section{P-1548. TR-10-1-40C}

Charcoal from carbonized wood beneath construction fill of Structure E 3-1 and directly assoc with top layer of sterile volcanic deposit, predating any known occupation at Chalchuapa. Comment: MASCA corrected range: 4020 to $4330 \mathrm{BC}$.

\section{Honduras}

\section{Port Royal series}

Port Royal, Isla de Roatan, Islas de la Bahia, Honduras $\left(16^{\circ} 20^{\prime} \mathrm{N}\right.$, $\left.86^{\circ} 20^{\prime} \mathrm{W}\right)$ is an underwater site lying at $\mathrm{E}$ end of Port Royal Bay. Wreck was covered with sand and turtle grass. Water depth in vicinity varies from ca 1.8 to $9.1 \mathrm{~m}$. Ship thought to date at least AD 1515 (Sauer, 1966). Samples coll 1971 by J J Berrier, Jr; subm by H R Sharp, Univ Mus, Univ Pennsylvania, Philadelphia.

\section{P-1799. PR1 WD UP\#6}

$$
230 \pm 40
$$

Sample taken from lower deck, stern sec. Comment: MASCA corrected range: AD 1760 to 1670 .

\section{P.1930. PR1 WBP UP\#8}

Mahogany, a species of Swietenia, id by R C Koeppen, was from port bilge pump just aft of mast step. Comment: MASCA corrected range: AD 1680 to 1590 .

\section{Peru}

\section{F. South America}

\section{Chilca Canyon series}

Samples from prehistoric sites in dry canyon $4 \mathrm{~km}$ from central Pacific coast, $67 \mathrm{~km}$ S of city of Lima, subm by Frederic Engel, Inst Anthropol y Agric Precolumbina, Lima, Peru.

\section{P-1593. 12B-VII-3080}

Charcoal, Sample v 2521, from Level 100 refuse probably from hearth, from Village 12B-VII-3080, Chilca Canyon (12 $25^{\prime} 26^{\prime \prime} \mathrm{S}, 76^{\circ}$ $\left.38^{\prime} 39^{\prime \prime} \mathrm{W}\right)$ at alt $+450 \mathrm{~m}$. Sample dates a late Precolumbian village in a loma with circular huts surrounded by small walls. Coll 1967 by Bernadino Ojeda. Comment: $\mathrm{NaOH}$ pretreatment. MASCA corrected range: 1960 to 1950 BC.

\section{P-1605. 12B-V-206}

$1320 \pm 60$

Sample v 1166 is from a beam of house in Antival, Site 12B-V-206, upper Chilca Canyon ( $\left.12^{\circ} 15^{\prime} 30^{\prime \prime} \mathrm{S}, 76^{\circ} 24^{\prime} 30^{\prime \prime} \mathrm{W}\right)$ and dates possible late-Nascoid re-occupation yielding undecorated, undefined chocolatebrown pottery from large above ground houses and elaborate rectangular chulpas. Lower levels are pre-Chavin, with age of $3700 \pm 110$, GX-1833 
(pers commun). Coll by Frederic Engel. Comment: MASCA corrected range: $\mathrm{AD} 720$ to 600 .

\section{P-1844. 16A-II-40}

$5560 \pm 80$

Sample v 2990, from Level 100 of shell and refuse mound at Site 16A-KK40, Bay of San Nicholas, S coast of Peru (15 $15^{\circ} 13^{\prime}$ S, $\left.73^{\circ} 13^{\prime} \mathrm{W}\right)$ ca sea level. Coll 1970 by Frederic Engel and Bernadino Ojeda. Comments: $\mathrm{NaOH}$ pretreatment. MASCA corrected range: 4400 to $4510 \mathrm{BC}$. $(\mathrm{FE})$ : the range, 4400 to $4510 \mathrm{BC}$, confirms Strong's judgement about pre-agricultural character of shell mounds found along the Bay of San Juan, $\mathrm{N}$ of Harbor of Marcona, S Peru.

\section{P-1845. 11B-IX-390}

$3390 \pm 70$

Wood, Sample v 2781, from broken beam on floor of decorated building or "temple" at Los Trisos, Site 11B-IX-390 in Chillon Valley $\left(11^{\circ} 44^{\prime} 30^{\prime \prime} \mathrm{S}, 78^{\circ} 58^{\prime} 30^{\prime \prime} \mathrm{W}\right)$, alt $+550 \mathrm{~m}$. Coll 1970 by Frederic Engel. Comments: MASCA corrected range: 1680 to 1950 BC. (FE): the range, 1680 to $1950 \mathrm{BC}$, establishes preceramic character of this large complex, comparable with El Paraiso, ca $40 \mathrm{~km} \mathrm{~W}$, along S bank of Chillon R. Site 11B-IX-390 was considered late prehispanic, as it had been reoccupied, but architecture, with clay-plastered and painted walls, is typical of final phase of preceramic horizons.

\section{P-1846. 17B-V-740}

$630 \pm 40$

Charcoal, Sample v 2886, from Quebrade Honda, Site 17B-V-740 $\left(15^{\circ} 50^{\prime} 51^{\prime \prime} \mathrm{S}, 74^{\circ} 18^{\prime} \mathrm{W}\right)$, alt $+25 \mathrm{~m}$. Coll 1970 by Frederic Engel. Comments: $\mathrm{NaOH}$ pretreatment. MASCA corrected range: AD 1350 to 1260. (FE): dates large settlement of Quebrada Honda found in a rocky cove just $\mathrm{N}$ of Chala. Pottery shows Inca types, but large terraces found all around in the lomas are Nazca. Date seems slightly early for an Inca settlement.

\section{P-1848. 9a-V-10}

$3240 \pm 60$

Wood, Sample v 2791, from House 9, Level 3 at Culebras, Site $9 \mathrm{a}-\mathrm{V}-10$ on $\mathrm{N}$ coast of Peru $\left(9^{\circ} 56^{\prime} 42^{\prime \prime} \mathrm{N}, 78^{\circ} 14^{\prime} 8^{\prime \prime} \mathrm{S}\right)$ alt $+40 \mathrm{~m}$. Comments: $\mathrm{NaOH}$ pretreatment. MASCA corrected range: 1500 to 1680 BC. (FE): result places Culebras preceramic settlement where it was expected, in the last phase of preceramic horizons, with subterranean houses still being used, contrary to above ground houses found in Rio Seco and Asia for the same period.

\section{P-1849. 16C-X-140}

$4090 \pm 70$

Charcoal, Sample v 2877, from Level 100, Quebrada Vaca, Chala, Site $16 \mathrm{C}-\mathrm{X}-140\left(16^{\circ} 18^{\prime} \mathrm{S}, 73^{\circ} 24^{\prime} 30^{\prime \prime} \mathrm{W}\right)$ a preceramic site on a terrace overhanging beach, alt $+40 \mathrm{~m}$. Comment: $\mathrm{NaOH}$ pretreatment. MASCA corrected range: 2610 to $2920 \mathrm{BC}$. 


\section{Guadalcanal}

\section{G. South Pacific}

\section{Fotoruma Cave series}

Fotoruma Cave is in the Poha Valley, Guadalcanal I, British Solomons I $\left(9^{\circ} 25^{\prime} \mathrm{S}, 159^{\circ} 54^{\prime} \mathrm{E}\right)$. Top stratum represents World War II battlefield; bottom stratum dated by I-2874, $2920 \pm 110$ (pers commun) is earlier than earliest Melanesian radiocarbon date for is $\mathrm{E}$ of New Guinea. Samples coll 1966-1968; subm by William Davenport, Univ Mus, Univ Pennsylvania, Philadelphia.

\section{P-1941. P4}

$1030 \pm 40$

Charcoal ca $48 \mathrm{~cm}$ below datum (D3, E) from ash and charcoal underlying that dated by $\mathrm{I}-2876,765 \pm 95$ (pers commun). Comment: $\mathrm{NaOH}$ pretreatment. MASCA corrected range: AD 1000 to 800 .

\section{P.1939. P2}

$300 \pm 40$

Charcoal from earth oven ca $61 \mathrm{~cm}$ below datum (D8, H). Stratum is below that dated by I-2876, $765 \pm 95$ and above I-2875, $1310 \pm 100$ (pers commun). Comment: $\mathrm{NaOH}$ pretreatment. MASCA corrected range: AD 1630 to 1470.

\section{P-1942. P5}

$2550 \pm 60$

Charcoal ca $152 \mathrm{~cm}$ below datum (D5, E) from earth oven in stratum underlying P4. Comment: $\mathrm{NaOH}$ pretreatment, MASCA corrected range: 760 to 810 BC.

\section{P-1943. P6}

$2630 \pm 60$

Charcoal ca $183 \mathrm{~cm}$ below datum (D5, E). Age expected to be $>$ P5. Comment: MASCA corrected range: 800 to $900 \mathrm{BC}$.

\section{P.1940. P3}

\section{AD 1230}

$720 \pm 40$

Charcoal ca $185 \mathrm{~cm}$ below datum (D11, K) from earth oven in stratum below P5 and P6. Comment: $\mathrm{NaOH}$ pretreatment. MASCA corrected range: AD 1290 to 1200.

\section{Havasu Creek series}

$$
\begin{gathered}
\text { II. GEOLOgIC SAMPLES } \\
\text { A. } U S A
\end{gathered}
$$

Samples are from Havasu Creek, Arizona, coll 1969; subm by Robert Giegengack, Geol Dept, Univ Pennsylvania, Philadelphia.

General Comment (RG): this study endeavors to assess empirically the validity of radiocarbon dates of calcareous tufa (see Giegengack \& Ralph, mss in preparation), and is, thus far, successful for selected samples of stream-precipitated $\mathrm{CaCO}_{3}$ from Havasu Creek, Arizona.

The water of Havasu Creek rises from perennial springs and mixes turbulently with the atmosphere as it falls through $457.5 \mathrm{~m}$ in ca $16.1 \mathrm{~km}$ 
(10 mi) of flow. Loss of $\mathrm{CO}_{2}$ causes precipitation of $\mathrm{CaCO}_{3}$ on bed and bank obstructions as well as on foreign bodies that fall into the stream. Especialy interesting are fragments of wood falling into the stream as trees dies after their roots are flooded by channel changes caused by systematic growth and periodic collapse of tufa structures.

A point ca $16.1 \mathrm{~km}(10 \mathrm{mi})$ upstream from the confluence of Havasu Creek with the Colorado $\mathrm{R}$ was arbitrarily selected to represent the center of water seepage on the floor of Havasu Canyon. The number in sample titles refer to mileage downstream from the springs to points at which tufa-encrusted wood was coll.

We have assumed that the innermost cylinder of $\mathrm{CaCO}_{3}$ around each wood sample was precipitated shortly after the contributing tree died. Hence, an age difference between the outermost wood and innermost tufa is a crude measure of isotopic disequilibrium between the stream water, from which the $\mathrm{CaCO}_{3}$ precipitated, and the atmosphere, from which the wood carbon is derived, at the time the tree died and for the point in the stream course at which precipitation began.

Assuming no sample was carried downstream after precipitation started, then any systematic downstream decrease in age differences between wood and tufa dated samples expresses the rate of equilibration of the carbon-isotope spectrum in the atmosphere with that of the stream water, presumably as a result of turbulent mixing of the water with the atmosphere.

$6.49 \mathrm{~km}$ downstream of origin of Havasu Creek

$\left(36^{\circ} 15^{\prime} \mathrm{N}, 112^{\circ} 42^{\prime} \mathrm{W}\right)$

P-1632. 69HC 4.03W

$240 \pm 40$

AD 1710

$\delta^{13} C_{w}=+6.5 \%$

Wood, probably mesquite, encrusted with calcareous tufa.

\section{P-1642. 69HC 4.03T}

$17,410 \pm 420$ $15,460 \mathrm{BC}$

$\delta^{13} C_{w}=+25.9 \%$

Tufa encrusting wood Sample P-1632 (cf). Comment: tufa age less wood age $=17,170$.

$8.05 \mathrm{~km}$ downstream of origin of Havasu Creek

$\left(36^{\circ} 15^{\prime} \mathrm{N}, 112^{\circ} 42^{\prime} \mathrm{W}\right)$

\section{P.1987. 69HC 5.00W}

Wood, encrusted with calcareous tufa.

$$
\begin{array}{r}
<\mathbf{2 0} \\
\delta^{13} C_{w}=-2.91 \%
\end{array}
$$

P-2044. 69HC 5.00W

Wood, same as P-1987 (cf). Comment: R G thought wood should be older, thus more of same sample was dated. 


\section{P-1988. 69HC 5.00T}

$16,560 \pm 190$

$14,610 \mathrm{BC}$

$\delta^{13} C_{w}=+27.5 \%$

Tufa encrusting wood Sample P-1987 (cf). Comment: tufa age less wood age $=16,540$.

$9.25 \mathrm{~km}$ downstream of origin of Havasu Creek

$\left(36^{\circ} 16^{\prime} \mathrm{N}, 112^{\circ} 43^{\prime} \mathrm{W}\right)$

P.1899. 69HC 5.75W

$\begin{aligned} & \mathbf{1 9 0} \pm \mathbf{5 0} \\ & \mathbf{A D} 1 \mathbf{6 6 0} \\ & \delta^{13} C_{w}=-1.95 \%\end{aligned}$

Wood encrusted with calcareous tufa. Wood id by R C Koeppen as species of Populus, either aspen or cottonwood.

\section{P-1898. 69HC 5.75T}

$15,400 \pm 270$ 13,450 BC

$\delta^{13} C_{w}=+22.5 \%$

Tufa encrusting wood Sample P-1899 (cf). Comment: tufa age less wood age $=15,210$.

$9.66 \mathrm{~km}$ downstream of origin of Havasu Creek

$\left(36^{\circ} 16^{\prime} \mathrm{N}, 112^{\circ} 43^{\prime} \mathrm{W}\right)$

\section{P-1897. 69HC 6.00W}

$420 \pm 40$

AD 1530

$\delta^{18} C_{w}=-.97 \%$

Wood encrusted with calcareous tufa. Wood id as species of Populus, either aspen or cottonwod (R C Koeppen, $c f$ P-1899).

\section{P-1896. 69HC 6.00T}

$14,900 \pm 210$

$12,950 \mathrm{BC}$

$\delta^{13} C_{w}=+19.56 \%$

Tufa encrusting wood Sample P-1897 (cf). Comment: tufa age less wood age $=14,480$.

$10.83 \mathrm{~km}$ downstream of origin of Havasu Creek

$\left(36^{\circ} 17^{\prime} \mathrm{N}, 112^{\circ} 44^{\prime} \mathrm{W}\right)$

\section{P-1694. 69HC 6.73W}

Wood encrusted with calcareous tufa.

$$
\begin{gathered}
13,530 \pm 90 \\
11,580 \mathrm{BC} \\
\delta^{1 s} C_{w}=+27.4 \%
\end{gathered}
$$

P-1695. 69HC 6.73T

Tufa encrusting wood Sample P-1694 (cf). Comment: tufa age less wood age $=12,930$.

$11.51 \mathrm{~km}$ downstream of origin of Havasu Creek

$\left(36^{\circ} 17^{\prime} \mathrm{N}, 112^{\circ} 44^{\prime} \mathrm{W}\right)$ 
I-7343. 69HC 7.15W

Wood encrusted with calcareous tufa. Comment: sample was too small; thus, was dated by Isotopes, Inc.

\section{P-2039. 69HC 7.15T}

$14,800 \pm 190$ $12,850 \mathrm{BC}$ $\delta^{13} C_{w}=+27.00 \%$

Tufa encrusting wood Sample I-7343 (cf). Comment: tufa age less wood age $=14,780$.

$15.34 \mathrm{~km}$ downstream of origin of Havasu Creek

$\left(36^{\circ} 18^{\prime} \mathrm{N}, 112^{\circ} 45^{\prime} \mathrm{W}\right)$

\section{P.1631. 69HC 9.53W}

Wood encrusted with calcareous tufa.

AD 1770

$\delta^{13} C_{w}=-.45 \%$

$13,050 \pm 300$

$11,110 \mathrm{BC}$

P.1641. 69HC 9.53T

Tufa encrusting wood Sample P-1631 (cf). Comments: tufa age less wood age $=13,260$. $(\mathrm{RG})$ : P-1631 and -1641 were lying on boulder in center of stream and were probably carried downstream by a flood after precipitation of tufa had begun.

$15.61 \mathrm{~km}$ downstream of origin of Havasu Creek

$\left(36^{\circ} 18^{\prime} \mathrm{N}, 112^{\circ} 46^{\prime} \mathrm{W}\right)$

\section{P-2037. 69HC 9.70W}

AD 1380

Wood encrusted with calcareous tufa.

\section{P-2038. 69HC 9.70T}

$$
\begin{gathered}
16,830 \pm 240 \\
14,880 \mathrm{BC} \\
\delta^{13} C_{w}=+26.83 \%
\end{gathered}
$$

Tufa encrusting wood Sample P-2037 (cf). Comments: tufa age less wood age $=16,260$. (RG): samples were lying at margin of stream and were probably carried downstream by flood after precipitation of tufa had begun.

\section{REFERENCES}

Black, R F and Laughlin, W S, 1964, Anangula: a geologic interpretation of the oldest archaeologic site in the Aleutians: Science, v 143, p 1321-1322.

Braidwood, R J and Braidwood, L S, 1960, Excavations in the Plain of Antioch, I: Oriental Inst Pubs, v 61, p 157-168, 232-238, 509-511, 513-514.

Cook, J P and Mckennan, R A, 1970, The Athapaskan tradition: a view from Healy Lake in the Yukon-Tanana upland: Paper, 10th ann mtg, Northwestern Anthropol Assoc, Ottawa.

Dyson, Robert, Jr, 1965, Problems of protohistoric Iran as seen from Hasanlu: Near Eastern Studies Jour, v 24, p 193-217.

1969, Stolper house: Expedition, v 11, no 2, p 39-47.

Jacobsen, T W, 1968, Investigations at Porto Cheli-Halieis, 1967: Archaiologikon Deltion, v 23, p 144-148. 
Jacobsen, T W, 1969a, Investigations at Porto Cheli-Halieis, 1968: Archaiologikon Deltion, v 24, p 135-139.

1969b, The Franchthi Cave: Archaeology, v 22, no 1, p 4-9.

1969c, Excavations at Porto Cheli and vicinity, preliminary report II: the Franchthi Cave: Hesperia, v 38, no 3, p 348-381.

Laughlin, W S, 1963, Eskimos and Aleuts: their origins and evolution: Science, v 142, p 633-645.

Laughlin, W S and Marsh, G H, 1954, The lamellar-flake manufacturing site on Anangula Island in the Aleutians: Am Antiquity, v 20, no 1, p 27-39.

Lawn, Barbara, 1970, Univ of Pennsylvania radiocarbon dates XIII: Radiocarbon, v 12, p 577-589.

Mellink, M J, 1969, Archaeology in Asia Minor: Am Jour Archaeol, v 74, p 165, plate 42 , fig 7.

fig 7. 1970, Archaeology in Asia Minor: Am Jour Archaeol, v 74, p 165, pl 42,

P'ritchard, J B, 1971, The Phoenicians in their homeland: Expedition, v 14, no 1, p 14-23.

Rainey, F G, 1939, Archaeology in central Alaska: Anthropol papers Am Mus Natl History, v 36 , pt 4 , p 351-405.

1940, Archaeological investigations in central Alaska: Am Antiquity, v 5 no 4, p 299-308.

Ralph, E K, 1959, University of Pennsylvania radiocarbon dates III: Am Jour Sci Radiocarbon Supp, v 1, p 45-58.

Ralph, E K, Michael, H N, and Han, M C, 1973, Radiocarbon dates and reality: MASCA Newsletter, $v$, no $1, \mathrm{p} 1-20$.

Sauer, C O, 1966, The Early Spanish Main: Berkeley, Univ California Press, p 1-306.

Sharer, R J, 1969, Chalchuapa-investigations at a highland Maya ceremonial center: Expedition, v 11, no 2, p 36-39.

Stuckenrath, Robert, Jr, 1963, University of Pennsylvania radiocarbon dates VI: Radiocarbon, v 5, p 82-103. p $333-345$.

Stuckenrath, Robert, Jr, Coe, W R, and Ralph, E K, 1966, University of Pennsylvania radiocarbon dates IX: Radiocarbon, $v$ 8, p 348-385.

van Loon, Maurits, 1968, First results of the 1967 excavations at Tell Selenkahiye: Annales Archaeol Arabes Syriennes, v 18, p 21-32.

1969 , New light on the chronology of the middle bronze age from inland Syria: Am Jour Archaeol, v 73, p 276-277.

van Loon, Maurits and Buccellati, Giorgia, 1969, The 1968 excavation at Korucutepe near Elazig: Turk Arkeolji Dergisi, v 17, p 79-82.

1970, The University of Chicago-University of California excavations at Korucutepe, 1968: 1968 Yaz Calismalari (Middle East Technical Univ, Keban Proj Pub I, II) p 89-102.

van Loon, Maurits and Dornemann, R H, 1969, New sites in the Euphrates Valley: Archaeology, v 22, p 65-70. 